\title{
General Agreement on Trade in Services and Aviation Ground Handling Services -A Theoretical Perspective.
}

\author{
Sumangal Narendra \\ Indian Institute of Foreign Trade Qutub Institutional Area New Delhi March 2013
}

\begin{abstract}
This paper explores the status of the Air Transport in General Agreement on Trade in Services (GATS) vis-à-vis opening of the Aviation Ground Handling market. The study is focused on the developments in terms of open market access to aviation ground handling services and developments in the GATS Air Transport Review. The study attempts to find answers to the questions: Is there a need for extending the GATS coverage to include some more auxiliary services, especially the aviation ground handling services? India shows a steady growth prospects for the aviation sector. Recently, it has opened up the sector to Foreign Direct Investment of upto $49 \%$ in the airlines. What is the case for India? The study reveals that India, though having a steady growth in aviation sector, has been cautious in opening of the sector, especially the ground handling services market to foreign participation. It had followed the 'gradual change' policy in this service market since 2007. Another fact that emerged is that the Member States (of WTO) may file the commitments under GATS, in case of air transport, but it does not directly lead to open market access and face the overall constraints of the national policy and domestic regulations and primarily the airport infrastructure capacity constraints limiting the entry and consequent competition of open market access. Compliance of national and international obligations of safety and security in aviation operations also pose certain constraints in free or open market access. Conclusions and limitations of the study are included.
\end{abstract}

Key Words: Air transport services, ICAO, GATS, Ground Handling, Market access and Commitments.

\section{Introduction}

1.1. As the air transport trade is through the negotiated Air Service Agreements (ASAs) granting the traffic rights to the contracting States, it is exempted from the coverage of the General Agreement on Trade in Services (GATS), except for such auxiliary services which are not directly related to the 'traffic rights' granted under these traditionally negotiated Air Services Agreements (ASAs). These auxiliary services are included in the Air transport Annex. The air transport sector is stringently regulated basically for safety and security aspects of operation under the International Civil Aviation Organization's (ICAO) Chicago Convention of 1944. Member States of the ICAO Convention have been adopting the Standards (mandatory for the international aviation) and recommended practices under the Convention Annexes for various aspects of operation like safety, security, facilitation, licensing of personnel, environmental factors etc. through suitable incorporation in their respective domestic regulations. There are almost 3500 ASAs world-wide regulating the air transport bi-laterally and more recently, through multi-lateral, 'open skies' agreements. The States through the ASAs specify the 'traffic rights' -i.e. defining the limits of operation (slots, seats, routes), the service provider- designated airlines, conditions for operating flights etc. GATS came into being in January 1995, exempting the air transport from its coverage, mostly because it has been operating under these negotiated agreements ASAs, between the contracting Parties. Thus, the fundamental tenets of GATS of 'National Treatment' (NT) and Most Favoured Nation' (MFN) cannot be applied to the air transport under the 'traffic rights'. The auxiliary services however, which are not directly related to the 'traffic rights' only, are covered under the Air Transport Annexe of GATS. It is interesting to review whether the GATS Air Transport Annex in its present form fulfills the requirement of addressing the developments and changes in the air transport sector? Does it need to expand the coverage to add some more services? What is the status of ground handling services vis-à-vis GATS? What is the status of India's aviation sector and especially the policy in respect of the Ground handling services market?

1.2. Study of available literature regarding the air transport, liberalization policies, competition in the network industries, domestic regulation and market access, developments under GATS, especially with reference to its five-yearly mandated reviews of Air Transport Annex, revealed that while there is a considerable body of research available on air transport and its liberalization, the area regarding duality of international regulatory environment of air transport and enlarging the scope of GATS Annex on air transport by adding some more auxiliary services are in a nascent stage of research. The present study attempts to fill in this gap and explores the possibility of defining the status of ground handling services, comparing the two international forums to arrive at the most rational and result oriented possible forum to negotiate the liberalization of ground handling services. Role of ICAO regulator and GATS provision are examined to find out the relationship 
between the commitment in the schedules of the Member States under the GATS air transport Annex vis-à-vis the market access.

1.3. Present coverage of air transport under GATS is in the Annex. GATS provision specifically excludes anything affecting the traffic rights and services directly related to their exercise. Traffic rights are defined in paragraph 6 (d), to include the right for scheduled and non-scheduled services operations, types of traffic to be carried, capacity to be provided, tariffs to be charged and their conditions, criteria for designation of airlines, including such criteria as number, ownership and control.

1.4. GATS Annex on Air Transport Services includes only three auxiliary services, namely:

- $\quad$ Aircraft repair and maintenance; (part of CPC 8868),

- $\quad$ Selling and marketing of air transport services;

- Computer reservation services.

1.5. The traffic rights are referred to as the 'hard rights' meaning that they need basic authorization (in the form of formal arrangement/agreement) from the Governments of the countries involved to operate services to and fro, as distinct from the 'soft rights' which refer to the 'doing business activities'- auxiliary services, as distinct from the authority to perform flights to and fro.

1.6. The paper is divided into sections: first section deals with developments in the aviation sector, with special focus on India. Section 2 examines the status of emerging ground handling auxiliary services in the light of GATS provisions and their role in trade enhancement. It highlights issues involved in introducing competition in the ground handling services markets, its implications within the constraints of market peculiarities, safety, security of operations and cost benefits to the airlines are analyzed. Section 3 discusses the deliberations in WTO Council of second review of the Air Transport Annex are recounted and has a commentary thereon. In Section 4, Relevant issues in bringing them under the coverage of GATS, are discussed. Section 5 concludes, regarding the scope for expanding the coverage of GATS in aviation sector, way ahead and limitations.

2.1. The Airbus Global forecast for the air transport 2012 to 2031, indicates that the air traffic expects growth between advanced and emerging air transport markets at an average annual rate of 5.1\% as against the forecast of $6.6 \%$ of growth between emerging markets. Further, on a worldwide basis, traffic growth is expected to be $4.7 \%$ per year. It further states that the traffic carried by Middle East airlines is expected to grow at the highest rate of $7.3 \%$, accounting for $11 \%$ of all the traffic carried in 2031 . Freight traffic is expected to grow at a slightly higher rate of $4.9 \%$ and the traffic between the emerging markets will be at a highest rate of $5.7 \%$.

2.2. This translates into increased air services operations and consequent growing demand for ground handling services. The role of ground handling operations is like the conductor bringing together the entire orchestration of the air transport activities from the landing of the aircraft at the airport till its next take off. Ground Handling services have emerged as a growing market, to some extent as a response to the development in the industry. With the entry of Low Cost Carriers (LCCs), the industry is facing re-structuring. The LCCs are looking at the composite solution to their demand for cost effective ground handling services. Even though at present the Ground Handling is undertaken as a self handling activity by majority of airlines, individually or as a joint venture with an airport operator, other independent agencies and many specialist companies are providing these services.

2.3. Ground handling has been the focus of discussions at various forums- the regulatory- ICAO and GATS, stakeholders- IATA, UNCTAD, ACI, Airlines and airport operators, service providers, governments and academics. Keeping in view the growing size of the market, it has been attracting attention of all these stakeholders. GIA (2011) in its comprehensive global report on Airport Airside Services market has indicated that "in the future, airlines are predicted to increase outsourcing of ground handling jobs to low cost markets in order to focus on core activities. Sustainable profit margins in the industry will depend on increasing visibility, reach and consumer loyalty through widespread consolidation and superior service. Client lock-ins with longterm contracts is a major necessity to beat competition and meet challenges. Similar to several other industries, technology will dominate the future in services and companies need to take cognizance and be technologically savvy in all aspects. The global market for airport airside services is forecast to reach over $\$ 42.8$ billion by the year 2017, fuelled by globalization, rising air passenger traffic and international trade. Asia-Pacific and Middle East are projected to be the main growth centers for air traffic increase with a sturdy annual growth for the next few years. Hectic economic development, cross border trade, spurt in international tourism and popularity of low cost airlines will trigger further growth in the aviation sector".

2.4. Role of aviation in the nation's economy and global growth is very important. Growing economies like India, the demand for efficient and faster air transport is already increasing as is evident from the following table.1: 
General Agreement on Trade in Services and Aviation Ground Handling Services -A Theoretical

\begin{tabular}{|c|c|c|c|c|c|c|c|c|c|c|c|}
\hline $\begin{array}{l}\text { Passengers Growth } \\
(\%)\end{array}$ & 2000 & 2001 & 2002 & 2003 & 2004 & 2005 & 2006 & 2007 & 2008 & $\begin{array}{l}2009 \\
\text { E }\end{array}$ & $\begin{array}{l}2010 \\
\text { F }\end{array}$ \\
\hline Worldwide & 9.6 & -1.9 & -0.1 & 3.2 & 11.6 & 7.1 & 5.0 & 7.4 & $\begin{array}{l}-0.4 \\
\end{array}$ & -2.9 & 5.6 \\
\hline India & 5.7 & 9.0 & 7.2 & -2.9 & 10.1 & 21.7 & 23.5 & 31.5 & 21.3 & -6.9 & 11.9 \\
\hline \multicolumn{12}{|l|}{$\begin{array}{l}\text { Cargo Growth } \\
(\%)\end{array}$} \\
\hline Worldwide & 9.2 & -5.3 & 9.0 & 6.7 & 9.6 & 2.5 & 5.9 & 5.0 & -3.1 & -11.1 & 11.9 \\
\hline India & 14.0 & 8.2 & 6.8 & 6.6 & 8.9 & 19.8 & 9.7 & 10.4 & 10.6 & -1.0 & 13.5 \\
\hline
\end{tabular}

E-Estimated, F- Forecast

Source: ACEXC Research- www.acexc.com as on $20^{\text {th }}$ March 2013 based on ICAO Data to 2008, IATA Data 2009 (E) 2010 (F) and Airports Authority of India Forecasts

2.5. IATA's Special Report points out that India's potential is enormous. As reported, 'the market already has some 150 million travelers passing through its airports, and if Indians begin to travel with the same frequency as Americans, then the years ahead could see the market boom beyond the two billion mark. This will not happen quickly and is dependent on an expected increase in per capita GDP. Even so, by 2020 traffic at Indian airports is expected to reach 450 million, making it the third-largest aviation market in the world. Some 90 million passengers per annum (mppa) are projected to pass through Delhi alone'. Significance of the corresponding growth in demand for auxiliary services, growth in related sectors of tourism and hospitality market needs no further emphasis.

2.6. In the aforementioned context, Paulus, (2011) study is relevant. Commenting on ground handling services regulations in India, he presents a comparison with international policies and practices. His study primarily focuses on the policy for ground handling operations from 'safety' and security' angle and centres around the provisions in the regulations. A comparison with such policies around the world, including the EU Directive of 1996, introducing the competition in the ground handling services market has been carried out. It is concluded that the ground handling regulation in India (issued during 2007) is similar to that of Europe Council Directive 96/67/EC issued on $15^{\text {th }}$ October 1996 on access to the ground handling market at Community airports. The study recommends that preference must be given to aircraft operators in choosing from several different choices of ground handling services including that of self handling as per the ICAO recommendation, as aircraft operators are the primary recipient of this service.

2.7. Airlines consider ground handling operations especially those with passenger interface as the essential part of their service experience and like to have the option of self-handling. In case of LCCs, because of their cost-conscious business model, they prefer outsourcing the ground handling services rather than invest in costly equipment, manpower and incurring costs on their training, retention, liabilities on account of accident and damages etc.

2.8. Governments have been responding to the developments in the aviation sector, albeit at a slower pace, with necessary policy changes to provide an environment conducive for the business. It has been observed that the system of mostly bi-lateral ASAs and associated national ownership rules as well as prevailing attitude of competition authorities (on merger policy and on airport pricing) have been identified as the three pillars posing challenges to the air transport. Findlay and Round (2006) consider these as the most important factors, limiting adjustment in the international air transport industry. These 'pillars of stagnation' have been examined by these two researchers. They studied the impact of these factors on the air transport services liberalization and have concluded that these factors are not independent as also that the effective liberalization of trade and investment in air transport services depends on complementary regulatory reforms.

2.9. Air transport is tightly regulated since 1944 traditionally by the International Civil Aviation Organization (ICAO) for the signatories of the ICAO Chicago Convention of 1944. As against the ICAO Chicago Convention which lays down standards, mainly for safety and security in aviation operations for mandatory compliances by the Member signatories, GATS provides overall extensive flexibility for scheduling the commitments, to address the peculiar characteristics of air transport - network industry, traffic rights governing market access under the ASAs and the emergence of the importance and magnitude of the auxiliary air transport services over the decades.

\section{GATS and Ground Handling Services}

3.1 A very essential air transport operation bringing the aviation into being, is the aviation ground handling consisting mainly the passenger handling, baggage handling, cargo handling, fuelling and catering apart from aircraft cleaning, loading and unloading, security, general administration and supervision. Out of these, fuelling, catering, loading and security are very specialized services and there's a prominent limitation on competition in 
these areas. These are the services which are distinctly apart from the 'core'ground handling services, which are provided by the ground handling agents and consists of rest of the activities like passenger handling, baggage handling, representation, administration and supervision and ramp services.

3.2 IATA produced a Standard Ground Handling Agreement (SGHA), which is widely used. The SGHA lists the key elements of ground handling. It originally contained 14 types of activities but was amended in 2003 in order to re-group and re-allocate them into 8 types of activities, as listed below (Table 2):

Table 2:

IATA (SGHA) classification of ground handling activities - 2003

\begin{tabular}{|c|c|c|}
\hline \multirow{8}{*}{ 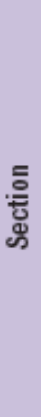 } & 1 & $\begin{array}{l}\text { Representation, Administration \& } \\
\text { Supervision }\end{array}$ \\
\hline & 2 & Passenger Services \\
\hline & 3 & Ramp Services \\
\hline & 4 & $\begin{array}{l}\text { Load Control, Communication \& Flight } \\
\text { Operations }\end{array}$ \\
\hline & 5 & Cargo \& Mail Services \\
\hline & 6 & Support Services \\
\hline & 7 & Security \\
\hline & 8 & Aircraft Maintenance \\
\hline
\end{tabular}

Source: IATA.

3.3 Ground handling and two of its sub-sectors, fuelling and catering, have been extensively described in the documentation prepared by the WTO Council Secretariat for the first review (compilation, pages 50-73, 49, 44-45). The sector has also been discussed by Members since the first review, and a report of these discussions, in particular on classification questions, can be found in document Job (05)/300, dated 18 November 2005 (for the various regulatory definitions and the possible GATS classifications).

3.4 Air Services Agreements (ASAs) deal with more than just the exchange of air traffic rights. The WTO Council for Trade in Services have through its paper in 2005, clarified status of measures directly linked to air traffic rights and measures that can be affected by an ASA, in case of mediation clauses. Accordingly, the measures that can be affected by the ASAs thus may be a part of the ASA, but it does not follow that measures affecting mediation are directly related to the exercise of the traffic rights under the ASA. The clarification is in the form of response to the Communication dated 15 Feb. 2005 from delegation led by Australia, comprising of Chile, the European Communities, New Zealand, Norway and Switzerland, followed by the Communication from Australia dated 05 Dec. 2007, as 'Review of Progress in Air Transport Services'

3.5 Do the GHS markets matter? The ground handling market is generally estimated at between US $\$ 30$ billion and US $\$ 40$ billion in annual turnover, depending on whether inter-plane fuelling, catering loading, security, and line (ramp) maintenance are included. The market in Europe alone is estimated to be worth approximately US $\$ 10$ billion. Given Europe's higher handling rates compared to North America, this would suggest that the global figure is closer to US\$30 billion than US\$40 billion.F. Gomez, D. Scholz (2009)studied the impact of technological and engineering improvements in the systems involved in providing various ground handling services on the 'turn-around' time for an aircraft and consequential benefits. Noting that Speed, efficiency and accuracy are important in ground handling operations in order to minimize turnaround time and ground handling costs, they recommend several new systems that can be adapted to the current aircrafts to improve the ground handling operations. Their results show that a $3.5 \%$ reduction could be achieved in the direct operating cost of the airlines.

3.6 Airlines and airports are estimated to control 75 per cent of the market, but increasingly these are disposing of ground handling, as it does not represent core business. Accordingly, commitments on ground handling are increasingly commercially meaningful. According to the report in the air transport review in the Council's document of July 2006, market shares of airlines, airports and independent ground handling providers show a change between 2000 to 2005, from higher percentage of shares of airlines and airports in the ground handling market reducing from $58.9 \%$ and $17.2 \%$ to $50 \%$ and $10 \%$ respectively. At the same time, the share of 'available' market for independent ground handling providers rose from $23.9 \%$ to $40 \%$ from year 2000 to 2005 . The 'available' markets or contestable markets are open to competition.

3.7 Before discussing the possible strategy to introduce competition in this market, it is important to assess the implications of 'regulatory' (ICAO \& Domestic) versus 'trade' (Bi-, Multi- lateral, Regional Agreements or under international trade forum of GATS) approach. Air transport is regulated by ICAO prescribed Standards 
and Recommended Practices (SARPs) for all areas of aviation operation- personnel licensing, aerodrome licensing, safety and security and environmental concerns. With the emergence of GATS as the platform for cross-border trade in services, air transport faces another question- what should be the interface between the ICAO and GATS for the aviation sector. GATS has a limited coverage of air transport in its Annex, exempting the sector except for the specified three auxiliary services which are not covered under or directly related to the traffic rights negotiated under the Air Services Agreements.

3.8 ICAO's Annexure 9 (Facilitation) Recommended Practice 6.6, states as follows: (ICAO, 2005):

'It is recommended that aircraft operators, in agreement with, and subject to, reasonable limitations which may be imposed by the airport operators, be offered the choice of providing their own services for ground handling operations, or the option of having such operations performed entirely, or in part, by an organization controlled by another aircraft operator authorized by the airport operator, or by the airport operator, or by a servicing agent approved by the airport operator'. The 'reasonable limitations' refer to the constraints of the safety and security vis-à-vis the airport infrastructure capacity constraints due to multiplication of the agencies, especially on the airside, leading to congestion. ICAO as such recommends a limited opening of the market for GHS.

3.9 GATS essentially, provides a structure in which policy makers can commit to sets of policy changes in the transport sector, including policy with respect to entry by domestic as well as foreign participants. This requires that the States scheduling their commitments also make appropriate legislative provisions in their domestic regulations. The domestic policies and regulations require mandatory compliances, whether they cover the operational sector of air transport, auxiliary services or the financial sector. These are dependent on the various factors like status of economy of the particular State, its national economic, competition and industrial policies, legislative framework and in case of developing, least developed countries, the primary concern of protecting the home industry and business commercial activities. Regulations of the air transport for safety and security at national level as also at international level under ICAO provide a primary framework for the aviation operations safety and address individual national security concerns. This poses a consequent constraint on unconditional open market access, even for the three auxiliary services of air transport covered under GATS.

3.10 ICAO secretariat (2000)brought out a paper on the emerging trends and changes in air transport, with reference to the ground handling. It pointed out that ground handling is one of the important aspects of the international air carrier's operations which affect the exercise of its basic market access rights. ICAO pointed out that GHS is also an important factor for air carriers in terms of operating costs, service level and competitive image offered to users. As mentioned in this paper, Ground Handling is provided at a considerable number of airports by the airport operators themselves, though at most of the airports it is provided by the national airlines/airlines or the concessionaires. Regulatory practices differ from State to State, especially with reference to the openness of business environment- ownership and control, Foreign Direct Investment (FDI), safety and security. Progressive liberalization of the air transport observed over the past 10-15 years and corresponding developments in the industry, is also being reflected in the way the air lines and airports are conducting their businesses. The Paper notes that the traditional monopoly of airports, bias towards the national carriers for designated status under the bi-lateral services agreements, self handling and providing the third party handling services at home bases are changing. Privatization of airports through the 'Operation, Maintenance and Development Agreements', adopting the 'Public-Private-Partnership Mode for infrastructure and capacity developments are becoming preferred choices. With the entry of different business models - the Low Cost Carriers (LCC), 'open skies' policies moving towards the multi-, plurilateral agreements, regional and preferential trade agreements, States are also fine-tuning their policies towards these changes.

3.11 In India, the Director General of Civil Aviation in 2007 issued Aeronautical Information Circular (AIC) granting the permission to the ground handling agencies to provide ground handling services, as a joint venture with the national carrier and/or Airports Authority of India, apart from the existing GHS providers - the Air India/Indian Airlines and the Airports Authority of India. In 2010, vide its Aeronautical Information Circular (AIC) no. 03/2010 dated 02nd June 2010, revised this circular and allowed, in addition, 'any other ground handling agent handling service providers selected through competitive bidding on revenue sharing basis by the airport operator subject to security clearance by the Government and observance of performance standards as may be laid down by the airport operator. A minimum of two ground handing service providers have been allowed to be authorized at the six metro airports in addition to the subsidiaries of National Aviation Company of India Ltd.

3.12 The airline operators protested the policy and the Federation if Indian Airlines along with other airlines filed a writ petition in the Delhi High Court stating that the private airlines are only given permission to be involved in ground handling activities where passenger interface is required. Ground handling also involves various critical services which are not visible to the passengers. The petition points out that Ground handling services are an integral part of any airline's business and it is essential to enable the customers in differentiating the service of one airline from another. Since the inception of civil aviation in India majority of the member airlines were providing self-ground handling services or sub-contracting it to an airport or handling agent or 
another airline, who can satisfy the specific tailor-made requirements of an individual airline. The Circular of DGCA dated 2-6-2010 laid down additional provisions allowing all private airlines, including foreign airlines, to undertake self handling in respect of "passenger and baggage handling activities at the airport terminals" and "traffic service including the passenger check-in", which require passenger interface, at all airports." Thus this circular prevents/prohibits the airlines to provide ground handling services where there is no passenger interface. The Petitioners have challenged this AIC No: 3/2010 dated 2.6.2010, to the extent that it precludes the private airlines from conducting ground handling operations which does not involve passenger interface It is alleged that the circular is anti competitive as it creates monopoly in favour of a selected few ground handlers and will lead to cartelization by independent ground handlers.

3.13 In India, the regulation of the airport charges including the ground handling fee rates is entrusted to Airports Economic Regulatory Authority (AREA) set up under an Act, to determine the tariff for the aeronautical services, to determine the amount of the Development Fees in respect of major airports and to determine the amount of the Passengers Service Fee levied under rule 88 of the Aircraft Rules, 1937 made under the Aircraft Act, 1934. AERA through its orders prescribes the maximum (capping) tariff rates for such services including the ground handling operations by the handling agencies after considering their 'Multi-Year Tariff Proposals' (MYTP). It had also issued guidelines in 2011, vide Direction no. 4/2010-11 dated 10-01-2011, defining the terms and conditions for determination of tariff for services provided for Cargo Facility, Ground Handling and Supply of Fuel to the Aircraft. These are finalized in an Order after the consultations with all stakeholders.

3.14 It will thus be seen that in India, the Ground Handling Services markets, at present are not completely open and are economically regulated as the prices are allowed to range within the maximum cap set by the regulatory body. This prevents the market forces to operate freely and release the cost and efficiency benefits to the customer airlines. The policy envisages a cautious and limited opening of the GHS market. This compares well with the policy directives, its review and recent revised Directive issued by the EU, opening their GHS market in a similar, very limited fashion.

3.15 Self (ground) handling by airlines is a practice followed all over the world. In major international airports like Newark \& John F Kennedy (United States of America), London Heathrow (United Kingdom), \& Melbourne (Australia), the airline operators are permitted to provide self ground handling in both ramp and terminal side operations. The Government of India has entered into various Bilateral Agreements with several countries. Many such Agreements inter alia, contain the clause:- "Each designated airline shall have the right to perform its own ground-handling in the territory of the other Party ("self-handling") or, at its option, select among competing agents for such services in whole or in part. The rights shall be subject only to physical constraints resulting from considerations of airport safety. Where such considerations preclude self-handling, ground services shall be available on an equal basis to all airlines; charges shall be based on the costs of services provided; and such services shall be comparable to the kind and quality of services as if self-handling were possible." This is on the lines of the standard clause for ground handling operations prescribed by the IATA too, for incorporating the same into the bi-lateral ASAs.

3.16 EU vide it Directive of 1996- EU 96/67 opened its ground handling market effective from Jan 1997. As per the said directive, a minimum of two ground handlers should be providing ramp handling subject to meeting specified criteria. M/s. SH and E ltd. studied the quality and efficiency of the ground handling services in pursuance of the EC directive 96/67/EC at the EU airports, focusing on the question of balance between different interests and implementation issues. The SH\&E Report states that a reduction in prices was seen as the positive impact of the said directive on the Member States where formerly there was a monopoly regime. The extent of price reduction was however, different for different Member States but there was increase in competition at virtually all airports, where the size of the contestable market was big enough to accommodate several suppliers for all segments of services, particularly for ramp handling. No consensus however, was available for impact of the Directive on the quality of Service.

3.17 European Parliament (EP) has adopted its Position on ground handling services at EU airports. It contains a revised set of rules which opens the market and only protects some categories of workers in case of call for tenders or partial loss of activities. The European Transport Workers' Federation (ETF) is highly concerned about a new Regulation that discriminates in the protection of workers with unnecessary job losses in the ground handling sector as a consequence. The ETF, representing more than 130,000 ground staff workers, regrets that the EP has decided to support the Commission proposal to further open the market. Regardless ETF's view that some efforts have been made to socially improve the Commission proposal, more needs to be done to ensure a proper protection of the ground handling workers. 


\section{Review of the GATS Air Transport Annex}

4.1 Considering that the air transport is a network industry, air transport liberalization indicator would be the market access in mode 3- commercial presence and mode 4-presence of natural persons. With a view to opening it up for competition in terms of 'market access' in at least mode 1, 2 and 3 (viz. Cross-Border Supply, Consumption Abroad and Commercial Presence, respectively) throws up very complex scenarios due to duality of regulation at international levels, domestic policies and regulations and safety and security concerns. In the circumstances moot question is whether liberalization of the aviation ground handling services market will actually lead to the increased competition and desired market access or would remain the theoretical exercise on paper?

4.2 Liberalization in the ground handling services market in the context of trade in services provides a dichotomy of regulatory environment. General Agreement on Trade in Services (GATS) Air Transport Annex exempts measures affecting air traffic rights and services directly related to the exercise of these rights for all but three specifically listed services from the Agreement's cover. Air transport liberalization from bi-lateral to 'open skies' and perhaps to the common civil aviation areas, a need is felt to consider market forces rather than long drawn discussions regarding the roles of these two regulators -ICAO for safety and security in civil aviation operations and safeguarding the environment and second one GATS, providing the platform for the states towards an open global market. It is also necessary to consider the operation of air transport under these two regimes as a complementary process and not contradictory elements.

4.3 Coming to the status of the aviation auxiliary services covered under the GATS Annex, the same contains a 'built in' agenda mandating the WTO members to reopen the market access negotiation. In 2001, WTO resumed the mandated five-yearly review of the Annex on Air Transport Services and adopted the guidelines, procedures and work programme for negotiation on services, including a number of air transport and tourism proposals for addition to the GATS Annex. Proposals for addition to the Annex on Air Transport Services included multi-lateralization of ground handling services, airport management services, leasing and rental of aircraft without the operator and services auxiliary to all modes of transport when delivered in the air transport context. However, this review was inconclusive as regards the expansion of the air transport Annex is concerned.

4.4 Council for Trade in Services has published a Report of the second review of air transport services as mandated in the GATS Air Transport Annexure. Firstly, it was noted that there was a continuing trend towards the private and often independent provision of ancillary services. On ground handling it was noted that there was essentially three types of services providers: airlines providing self-handling and third party handling, particularly to alliance partners, airports their subsidiaries and independent handlers. In fact now, the GHS are being provided in addition, increasingly by the Joint Ventures of airlines, airports and GHS providers as also the independent GH services providers. Number of players has increased. However, it was noted in the said Review that considerable differences remained in the level of access for each of these categories, leading to inefficiencies and in some cases, abuse of market power. Industry has been urging the States to open the ground handling market where space permitted.

4.5 The Council addressed the submission contained in the Paper jointly sponsored by Australia, the European Communities, New Zealand, Norway and Switzerland and titled "Review of the Annex on Air Transport Services - Ground Handling and Airport Operation Services". A group of six Members (Australia, Chile, European Communities, New Zealand, Norway, and Switzerland) co-sponsored a collective request on Air Transport Services pursuant to paragraph 7 of Annex C of the Hong Kong Ministerial Declaration. The request, inter alia, seeks commitments on ground handling services (container handling services for air transport services only (part of CPC 7411), other cargo handling services for air transport services only (part of CPC 7419), other supporting services for air transport (CPC 7469)), and airport operation services (airport operation services (excl cargo handling CPC 7461)). These elements of the request are made without prejudice to parallel developments in the GATS Air Transport Review. Commitments in all these air transport service sectors are sought across all four modes of supply.

4.6 In addition, since the last meeting, a new communication had been tabled by the delegations of Canada and the United States and circulated as JOB(07)/143, dated 28 September 2007 (and Corrigendum 1, dated 2 October) and titled "Second Air Transport Review".

4.7 United States of America (USA) and other certain WTO members consider that the ground handling and airport operation services are excluded for the coverage under the GATS Air-transport Annex. as reported in the Report on the second session of the Review mandated under Paragraph 3 of Annex on Air Transport services (held on Oct. 2007). During the discussions, divergent views emerged with reference to the scheduling commitments under the Annex for the services which were not explicitly mentioned therein like ground handling and airport operation services. USA felt that there is a need to preserve the legal certainty of the provisions of Annex. USA opined that it is necessary to amend the Annex rather than leaving it to the Members to independently and variously interpret the scope of the Annex and enable Members to schedule commitments 
in these and other such services. Canada enquired as to exactly how the process of amendment of the Annex would be to achieve the same. Further, in their perception the universe of GATS and aviation are very different and their compatibility is an open question that needs a careful assessment at national level. USA raised some questions during the Second Review deliberations wanting to know the description of legal process, stepwise, through which the Annex would be amended, what would be the implications of the proposal of Australia, EU et al, on current MFN exemptions and on the possibility of lodging new MFN exemptions based on proposed new extended list of services in paragraph 3 of the Annex? USA also wanted to know if Members have a similar opportunity to make technical explanatory corrections to their schedules? And lastly, would there be an opportunity to revisit the definition of ground handling services and airport operation services currently contained in the co-sponsors' proposal to ensure that these definitions accurately reflected the the regulatory environment in which they are provided?

4.8 Australia, one of the co-sponsor of the proposed extension of the Annex for these services presented Australia's view stating that Article X of the Marakech Agreement provided a mechanism to take forward the proposals to amend the WTO Agreement. Such an amendment could be adopted at a Ministerial Conference level but also, legally speaking, at the level of the General Council. It was further pointed out that while a recommendation of the regular Council for Trade in services stemming from the Review process was not necessary but was preferable. As regards the point raised by USA regarding the MFN exemption, Australia recalled that these two sectors were in its view already covered by the GATS and that therefore there was no particular need for new MFN exceptions, as most of the air agreements were dealing with the rights of airlines to self-handle and not with the rights of independent ground handlers to provide services. As regards, the definitions, Australia voiced that in a GATS, positive listing context Members were always free to define sectors as they saw fit.

4.9 USA however, opined that there is a problem with regard to ground handling and MFN. Various US Statutes within aeronautical codes and notably the International Air Transportation Fair Competition Practices Act required that DOT implement reciprocal treatment and retaliate against the unfair, anti-competitive practices by foreign entities. This requires a protection of MFN exemption, as in case of CRS and other services now covered under GATS.

\section{Discussion and Analysis:}

5.1 Market access negotiations in the air transport services are being carried out since Hong Kong Ministerial meeting. Paragraphs 1, 2, 6 and 7 of Annex C of the Hong Kong Ministerial Declaration are relevant in this context. As per the recently mandated review required by the GATS Annex on Air Transport Services showed that a whole sector has developed that provides a range of aviation related services including the ground handling services, that were previously being provided by the airlines.

5.2 A significant number of WTO Members have already made commitments to policy applied to transport services. However, there are some important exemptions that remain to be negotiated or reviewed, including in maritime and air transport. At present 64 Member States have filed their commitments in the schedule under '11.c- Air transport'.

5.3 Adlung (2004) in the preliminary stocktaking after GATS turned ten, has presented the details of types of 'Market Access Limitations Scheduled by WTO Members under Mode 3', in 2004. It provides an overview of the limitations scheduled under market access for mode 3, the commercially most relevant mode of supply. The Chart of Adlung (2004) below (Figure 1) features the six types of measures provided for under Article XVI:2, complemented by two residual categories covering imprecise or even flawed entries. Disturbingly, these are the two largest categories.

5.4 Figure 1: Types of Market Access Limitations Scheduled by WTO Members under Mode 3,

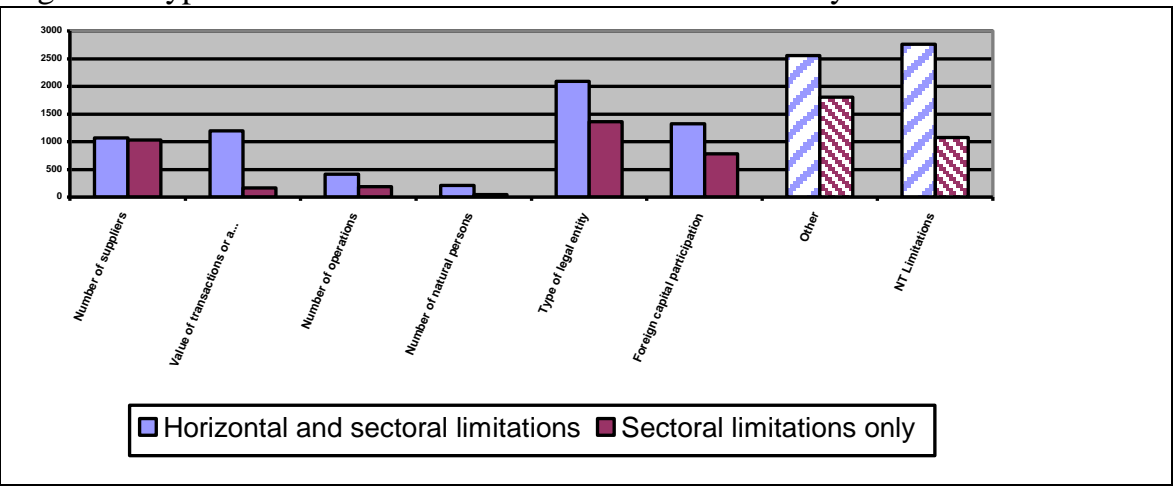




\section{5 arch2004: Source: WTO Secretariat}

5.6 Scheduling the Commitments for the three clearly included auxiliary services are also limited with the MFN exemptions and horizontal commitments and more often than not present themselves rather as constraints on the intended objective of liberalization and facilitation the trade in services. As regards the two identified additional services that could be considered to be brought within the purview of the Annex, the exclusion of measures affecting traffic rights and services directly related to the exercise of the traffic rights makes it easier to take commitments on ground handling under GATS Annex on Air Transport Services. However, it is essential that 'ground handling services' and the terms with reference to ground handling and its supply are defined clearly and the Paragraph (3) of the said GATS Annex is amended to include these.

5.7 Despite the debate whether Ground Handling services are covered under the Air Transport Annex of GATS and as such deserve the treatment at par with other three auxiliary services namely, aircraft repair and maintenance, selling and marketing of services and computer reservation system, it is essential that ground handling services are defined clearly and cogently in both the WTO GATS Annex and under the ICAO regulations. ICAO, the UN international organization exclusively addressing the safety and security, operational regulations and laying down Standards and Recommended Practices, is considered to be the proper forum for a debate on whether or not, the Ground Handling Services are 'directly' related to the 'traffic rights'. As the ASAs have specific provision on supply of GHS, there are arguments that these are directly related to the traffic rights defined under the ASA.

5.8 As regards the characteristics of the ground handling are concerned, different aspect of these activities has different degrees of complexities and different levels of costs. The specialized services of fuelling, catering, ramp services, loading cargo and baggage, involve specific hi-tech equipments, skills and capacities. These are also the services which form the non-competitive component. On the other hand, passenger handling, baggage handling, support services, administration and surface transport etc. are comparatively simpler operations, costs of equipment and manpower training and supervision and providing the services are not so prohibitive. These form the competitive part of the services where the entry of third party independent handler is expected.

5.9 Market access, liberalization need to include the ground handling services in the Annex but must take into account the implications of the industry developments like air lines alliances and code sharing, mergers and acquisitions, outsourcing activities, operations involving foreign registered aircraft especially problems posed by 'flags of Convenience', foreign flight crew, 'off-shore' operations, operations involving multiple parties and use of the other's brand - such as code-sharing and franchising etc

5.10 A study was undertaken by the ICAO secretariat in order to determine if the existing provisions of the ICAO can meet the safety and security challenges in the changing liberalizing, globalizing commercial and operating environment. A review was undertaken of various situations in the areas of ground handling, outsourcing and commercialization/privatization of airport and air navigation service providers. The review found that safety and security issues arise mainly from those commercial arrangements or practices which impinge on the operation of aircraft or the operating personnel. These are important issues in the situations involving multiple States which could raise questions regarding the delineation of accountability or responsibility for safety / security oversight under the existing regulatory system based on ICAO provisions. Such situations have a complexity of issues especially in respect of operations involving foreign registered aircraft, operations involving foreign flight crew, 'Off-shore' operations i.e. flight operations away from the designated State, State of registry or State of the operator, operations involving multiple parties and the use of other's brand, cross-border airline merger/acquisition and outsourcing of activity affecting aircraft operation.

5.11 So far, sixty four countries have scheduled their Commitments for Air Transport sector. Canada, Japan, and the United States agreed with the view that ground handling is becoming a major service within the international aviation industry, with the role of third party ground handling service providers slowly growing in importance. However, they have categorically stated that they do not agree that the GATS currently applies to ground handling services, and, therefore, do not agree that it is possible for Members to take specific commitments in ground handling services at this time. They further argued that if Members wish to extend the coverage of the GATS coverage to include ground handling, they must do so through a formal amendment to paragraph (3) of the Air Transport Annex that would add 'ground handling' as a fourth item to the exhaustive list. Canada, Japan and the United States believe that the proper forum to discuss such an amendment is through the Air Annex Review. In this forum, air transportation experts can discuss the issues surrounding ground handling. The second review of the Air Transport Annex is underway and it is expected to receive the communications arguing both for inclusion and exclusion of the 'Ground Handling Services' within the purview of the GATS.

5.12 The Members having scheduled the commitments for air transport have also filed the horizontal commitments across the sectors which put restrictions on market access on the principle of MFN and the national treatment- the two essential principles of GATS. There are regulatory and policy restrictions in the form of conditions of ownership, management, operation, juridical form and scope of activities as set out in a license 
or other form of approval establishing or authorizing the operation or supply of services by an existing or potential foreign service supplier.

5.13 Notwithstanding the positions taken by the Member States about scheduling the commitment for Aviation Ground Handling Services under the Air Transport Annexe, it is certain that the ground handling services market liberalization is the essential and the first step towards trade in services. With the horizontal commitments, maintaining the constraints of Ownership, Control, Limits on number of suppliers, pre-defining Form and capital structure of Independent Ground Handling services providers, any commitment, even if filed in the schedule for the ground handling services by the Members for the Aviation ground handling services will not lead to the actual open market access to the independent, other services providers.

5.14 Researchers and academic studies of the relevant issues point towards certain impediments to the negotiations under GATS owing to the 'acuteness of regulatory concerns', which are more difficult to address in WTO than for example in the context of supranational/regional organizations, such as EC. The trade effects that might be associated with policy bindings are certainly more difficult to trace than they already are in merchandise trade. This is due to particular structure of GATS, having four modes of supply and wide range of permissible trade restrictions. In this context there is a scope for further study in the Aviation Ground handling Sector so as to find out the issues and possibilities of comparable GATS-bound liberalization in certain countries/ Group of countries and linkage with non-bound liberalizations in others. Exploring the extent of influence on investment decisions by the existence of specific commitments under GATS and the associated stability effect is another possible area of research.

5.15 Researchers and WTO experts have already concluded that the binding of services regimes comes only at the end of potentially lengthy process of country- and government process of internal policy reflection and coordination. Growth and adjustment related objectives, revolving for example around the investment promotion are balanced with a perceived loss of 'policy space' and the risks associated with unintended and/or ill-specified commitments. Some of this policy space might be more apparent than real, however, given the bindings assumed under investment treaties. Investigating the trade-off between the 'Commitment' and 'Policy Space Loss' and the extent of its impact with reference to liberalization of additional auxiliary air transport services, especially the ground handling market, could be another area of future research.

\section{Findings and Conclusion}

6.1. It has been revealed in the documentation of the various reports and the initial deliberations regarding the issue of whether to expand the coverage of the Air Transport Annex of GATS to include the distinctly emerged two auxiliary services, namely the ground Handling and Airport Operation Servcies, that unless the domestic regulatory policies are harmonized towards the reduction or elimination of such conditions for market access, no half hearted filing of commitment can lead to actual market access. Mere commitments under the Sectoral category along with simultaneous 'MFN' and 'national treatment' exemptions- horizontal commitments, constraints in the horizontal commitments for Mode 3 and Mode 4 defeat the very objective. Further, as already noted in these deliberations, the issues not related to economic liberalization like safety and security of air transport operations need to be addressed fully before a full-fledged expansion of GATS Annex is undertaken and commitments on additional auxiliary services especially the ground handling are taken. There is a need for extensive discussions on the 'request-offers' received on the issue of inclusion of Ground Handling Services in the Annex as pointed out by the Members in the second review of the Annex. These are expected to be long drawn complex debates in the context of regulatory developments.

6.2. Further, as pointed out by the Members a consensus is necessary, in the first instance, regarding the definition of 'services not directly related to the traffic rights'. No negotiations can be possible if there is a difference in perception regarding certain important aspects like- (i) are the identified auxiliary services like ground handling, not directly related to traffic rights? (ii) what should be the interface for ICAO and WTO regulations to have distinct and unambiguous coverage of this auxiliary ground handling services under these two regulators, of trade in air transport services, (iii) convergence of national policies on Competition, fiscal policies, Customs impediments and infrastructure access need to be addressed in right earnest to effective harmonization and towards an unified goal of 'open market access'.

6.3. Adlung (2004) states that although the 'Open Skies' agreements have dramatically improved the situation in some markets, many important issues are still strictly controlled, e.g., ownership and control, cabotage, and the right of establishment. Thus, in his opinion, even the Open Skies model preserves many of the anachronisms that distinguish the international air transport sector from most other globalized industries. These restrictions prevent free trade in air transport services and optimal capital movement. As a consequence, these factors push up costs of production. National differences in the way these market impediments operate also make it difficult in the current bilateral system to bring about intended changes 
6.4. The research and studies so far have concluded that 'Plurilateral and multi-lateral agreements', concepts of 'Common' and 'Open' aviation areas are certainly the way forward. Discussions and resolution of questions of legal jurisdiction, safety and security issues are pre-requisite to liberalization objectives.

6.5. Potential path to further liberalization in case of the air transport services under GATS, through evolution of the bi-lateral, to plurilateral, multi-lateral and regional agreements in the light of regulatory developments under GATS and ICAO, could also be explored vis-à-vis the convergence issues for harmonized legal framework- competition policy to recommend some concrete steps to increase the commitments.

\section{References:}

[1] Global Market Forecast-2012-2031--Airbus

[2] Global Industry Analysts, Inc., (GIA) viewed on October 8, 2013.

[3] http://www.iata.org/publications/airlines-international/october-2012/Pages/india.aspx on 04-10-2013

[4] Paulus, Nilanthi Cassia, (2011) - Ground Handling Regulation in India-A comparison with international policies and practices', School of Aerospace, Mechanical and Manufacturing Engineering, RMIT University, Australia

[5] Findlay, Christopher and David K. Round, (2006)- The 'three pillars of stagnation': challenges for air transport reform. World Trade Review, 5, pp 251-270.

[6] WTO (July 2006), 'Air Transport and the GATS- 2000-2005 in Review - S/C/W/270, pgs 71-72.

[7] WTO Paper (2005), 'Air Transport Services', Information Note by the Secretariat, Council for Trade In Services, Job (05)/300 dated Nov. 2005

[8] Council for Trade in Services (2007)- 'Communication from Australia'- Review of progress in Air Transport Services, Dec. 2007Job (07)/211

[9] WTO Note by the Secretariat(2006), 'Second Review of the Air Transport Annex-Developments in the Air Transport Sector (Part One)- S/C/W/270 18 July 2006 (06-3471) Council for Trade in Services.

[10] ${ }^{1}$ F. Gomez, D. Scholz, (2009)- 'Improvements to Ground Handling Operations and their benefits to Direct Operating Costs', Hamburg University of Applied Sciences, Deutscher Luft- und Raumfahrtkongress 2009, DocumentID: 121197

[11] WTO Council for Trade in Services, Special Session (2005), 'Trade in Services to the Aviation Industry: A case for commitments under GATS'-05-0651, TN/S/W/29 dated 16th Feb. 2005.

[12] ${ }^{1}$ WTO Note by the Secretariat(2006), 'Second Review of the Air Transport Annex-Developments in the Air Transport Sector (Part One)- S/C/W/270 18 July 2006 (06-3471) Council for Trade in Services.

[13] ibid

[14] Ground Handling at the Airports', presented by the ICAO secretariat at the Conference on the Economics of Airports and Air Navigation Services, Montreal, 19-28 ${ }^{\text {th }}$ June 2000- ANS Conf-wp/10.

[15] SH \& E International Air Transport Consultancy Final Report (2002)- 'Study on the quality and efficiency of ground handling services at EU airports as a result of the implementation of Council Directive 96/67/EC', viewed 25th July2012 http://ec.europa.eu/transport/air_portal/airports/doc/2002_ground_handling_final_report.pdf

[16] European Transsport Workers Federation's Ground Handling Campaign- http://www.itfglobal.org/etf/gh-campaign.cfm, viewed on $11-12-13$

[17] Council for Trade in Services, WTO (2007): Report of the Second Session of the Review Mandated Under Paragraph 5 of the Annex on Air Transport Services Held on 02 Oct. 2007- S/C/M/89 dated 19 ${ }^{\text {th }}$ Nov. 2007

[18] Council for Trade in Services (2006) "Review of the Annex on Air Transport Services - Ground Handling and Airport Operation Services"JOB(06)/237, dated 13 September 2006.

[19] WTO Council For Trade in Services- Report of the Second Session of the Review Mandated under Paragraph 5 of the Annex on Air Transport Services held on 02 ${ }^{\text {nd }}$ October 2007- S/C/M/89 dated $19^{\text {th }}$ Nov. 2007.

[20] Adlung, Rudolf (2004)- 'The GATS Turns Ten: A Preliminary Stocktaking- World Trade Forum, Staff working paper ERSD-200405, WTO Economic Research and Statistics Division ibid 